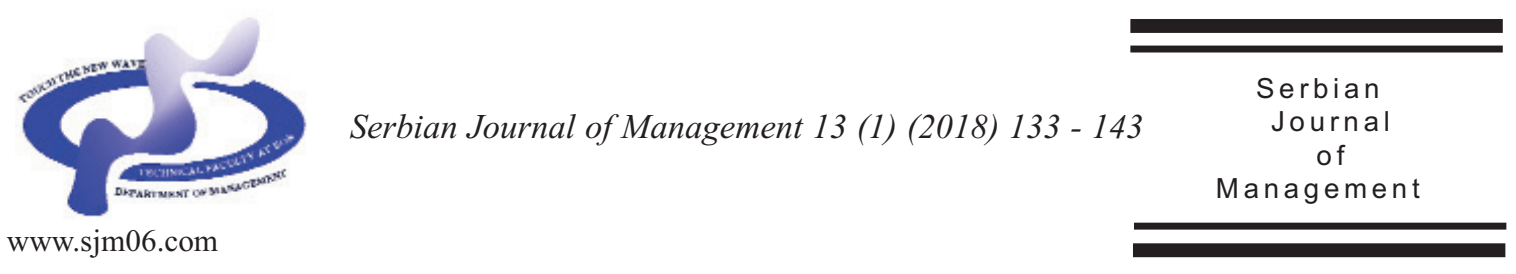

\title{
MODELING OF DYNAMIC PROPERTIES OF NATIONAL ECONOMIC SYSTEMS
}

\author{
Vitaliy A. Koroleva, Yevgeniy L. Toroptsev ${ }^{a}$, Lyudmila G. Matveevab \\ and Olga A. Chernova ${ }^{\text {b* }}$ \\ $a_{\text {North Caucasus Federal University, Institute of Economics and Management, Business }}$ \\ IT department, Marshal Zhukov Street 9, Stavropol, Russia

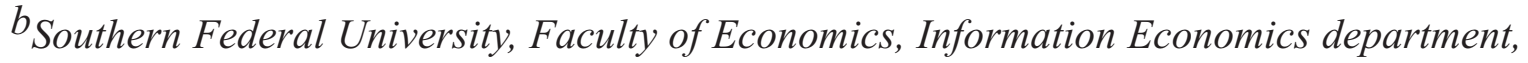 \\ Gorky Street 88, Rostov-on-Don, Russia
}

(Received 21 January 2017; accepted 12 May 2017)

\begin{abstract}
The objective of the article is to develop the modeling of dynamic properties of national economic systems at different hierarchic levels from the universal statistical and mathematical perspective of the economic system dynamics modeling theory. Taking into account the suggested model, the major factors in the economic development of the present-day Russia have been studied in the article. The methodology of socio-economic analysis has been applied to assess the impact of the identified factors on quantitative and qualitative indicators of the Russian economy development. The article describes the role of the analysis of national economy dynamic properties in increasing the efficiency of the national economy development strategies management in order to achieve structural and dynamic harmonization of innovative processes and economic growth.
\end{abstract}

Keywords: economic growth, national economy, national policy, dynamic properties of the system, economic system modeling, management by objectives

\section{INTRODUCTION}

As most national economies follow the innovative development paradigm to solve the problem of their higher competitiveness in the global market under conditions of increased globalization and influenced by a number of geopolitical challenges, national policy regarding major economic sectors which determine national macroeconomic policies needs improving. A set of economic and mathematical models that allow making efficient economic decisions on the implementation of management by

\footnotetext{
* Corresponding author: chernova.olga71@yandex.ru
}

DOI: $10.5937 /$ sjm13-12991 
objectives principles and mechanisms could serve as a toolkit and methodic basis to support innovative processes. Thus, the modeling of dynamic properties of national economic systems at different hierarchic levels is of crucial importance. The research of the dominant factors of economic growth within this modeling could solve a number of tasks on forecasting, optimizing and managing structural reforms, modernization, economic dynamics and economic growth.

\section{LITERATURE REVIEW AND METHODOLOGY OF THE RESEARCH}

Modern theories on economic growth are based on the neoclassical theory (Say, 1883; Jevons, 1905; Walras, 2000; Marshall, 2007; Clark, 2000) and Keynes's macroeconomic theory of general equilibrium (Keynes, 2011), according to which any economy is considered as a self-regulated mechanism capable of using all factors of production in the best possible way, which leads to profit maximization and costs minimization.

However, in real economies, and in modern Russian economy in particular, such equilibrium does not exist (Keller \& Shishkina, 2013; Kleiner, 1986; Salin, Medvedev \& Medvedev, 2012). This causes the need to identify the deviation of the real process from the ideal one by applying factor models, the example of which can be the model of Cobb-Douglas production function focusing on two major factors - capital and lab our. The general model of the production function may include much more factors. For instance, the theory of complex-valued production function introducing more advanced methods of economic analysis which are unattainable in the area of real numbers (Svetunkov \& Abdullaev, 2009) has been developed recently. But despite higher possibilities for the analysis, the theory and the models could be applied mostly to explain and interpret economic facts and, in rare instances, to determine future strategic development. R. Solow's and Tinbergen's models (Solow, 2010; Tinbergen, 1980) are purely macroeconomic and cannot be used in structural research. Applying the abovementioned models, a factor analysis of economic growth sources can be conducted; it enables a researcher to identify the relationship between national economic growth and the dynamics of savings and capital accumulation or the level of technological development. However, these models cannot be used to develop dynamic properties and structural reforms in economic systems.

Harrods's, Domar's and Hansen's neoKeynesian models as well as other models of this group have similar disadvantages (Harrod, 2008; Hansen, 2006). They can be used to establish cause and effect relationships, but do not offer the opportunity to forecast managerial impact on economic growth. At the same time, mathematical support of modernization management in national economic systems should provide identification of step-by-step structural shifts, changing dynamic properties of an economy as a system and establishing proportions in it which are desirable in terms of efficiency, new possibilities and long-term development perspectives of a country as a whole. In this respect, the strategic testing of the cooperation among different spheres of the national economy, financial and production sectors in particular, should be considered. It can be applied to building the model of efficient development of these processes taking into account timely identification and 
negotiation of the limiting factors. The latter are the financial sector elements which, on the whole, restrict possibilities of a macroeconomic system as a key factor of industrial modernization due to their underdevelopment for a number of reasons, and thus, determine major trajectory of managerial impact. In addition, the strategic testing of complementary dependence according to aims and tasks of financial and real sectors provides controlled implementation of the national social and economic development strategy and achievement of global goals (Matveeva et al., 2015).

\section{DIRECTIONS OF SOLVING THE PROBLEM AND THE RESULTS}

In our opinion, among many different economic dynamics models, Leontyev's model in its dynamic variation (Leontief, 1953; Leontief, 1997), which has a direct relation to 'input - output' methodology and analysis, should be paid due attention to.

$(E-A) X(t)-B p X(p)=Y(t)$

where $p=\frac{d}{d t}$ is the differentiation symbol symbol with respect to time,

$A$ is the matrix of direct tangible costs coefficients,

$B$ is the matrix of differential capital coefficients,

$Y(t)$ is the demand vector, $X(t)$ is the output vector, $E$ is the identity matrix,

$B(p) X(p) \quad$ describes the 'capital' accumulation / decumulation in proportion to the change in output from the macroeconomic perspective.
The system of equations is open-ended in consumption and has a quite complicated solution which depends on the particular type of the demand vector function $(t)$. In practice, this system can be closed if we introduce the assumption that demand is proportional to gross output applying matrix defined by labour efficiency and consumption standards:

$Y(t)=Q X(t)$

The open-ended system is based on matrix but the system itself is homogenous as it lacks exogenous variables:

$X(t)=G X(t)$

There is a matrix exponential and initial conditions in the solution of such system:

$X(t)=e^{G t} X(0)$

where $X(0)$ are initial conditions which determine the rates of gross output for the year when the integration process forecasting gross output under different changes in the model parameters begins.

The whole set of methods of the analysis and dynamic system management developed in technical sciences and economic cybernetics can be applied to the abovementioned models. They can be used to manage economic growth and other components of economy movement within time horizons which maintain linearity of the model. Moreover, the reach ability of the desired goals can be assessed within the framework of this model. The scaled-up examples of the problems solved may include the following:

- development of optimizing procedures 
to achieve stable and well-balanced economic growth by implementing structural reforms and modernization;

- creating balance models of economic systems with predefined dynamic properties and generation of efficient processes/laws of their management as well as solution of stability problem;

- mid-term and, in some cases, long-term forecasting of major national indicators based on reference year data, which comes though mathematical representation of the dynamic model of input-output balance in the form of Cauchy problem for ordinary differential equations.

It should be emphasized that monitoring, forecasting and economic dynamics management tasks based on the represented models are conceptually different from any traditional forecasting task models which use time series application analysis. This can be explained by the fact hat the guided paths of gross output balanced growth are determined by intrinsic dynamic properties of the subject of management, the deliberate changes in which could be valued in terms of time and money as well.

Let us examine the case of Stavropol region to consider possible ways of applying the described above models to assess the dynamic properties of economic systems at different hierarchic levels and analyze factors determining qualitative and quantitative indicators of macroeconomic dynamics. 15 major economic activities were modeled but the figures illustrate only those which are dominant in this region.

Exponential extrapolation of output in certain economic activities represented in

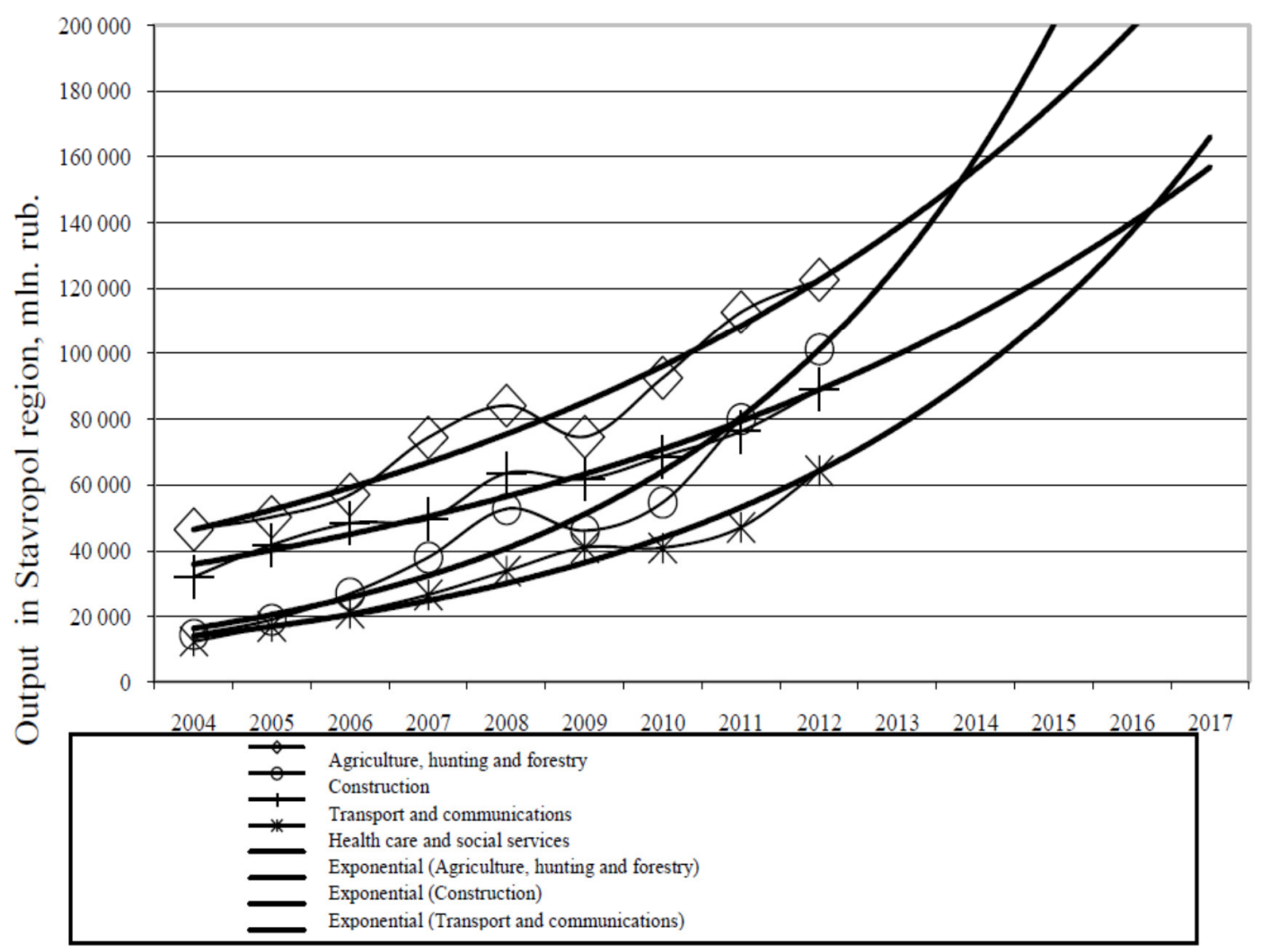

Figure 1. Gross economies of Stavropol region according to international economic activity 
figure 1 provides the evidence of the misbalanced economic development, which can be seen in the intersections of approximation trends.

The real data on gross output in different economic activities demonstrate variable trends, i.e. the rates of their growth and increment of growth witness misbalanced macroeconomic indicators both in the region and in the economy as a whole. Taking into account the linear character of the model, we can conclude that intermediate consumption, gross value added, the elements of gross regional product and other indicators are subject to similar misbalance.

According to the authors' experience in optimization calculations, the problem of managing the intrinsic dynamic properties of the economic system in question is controversial and diverse.

Several types of system behavior might be identified in terms of characteristic equation root positions (eigenvalues for the state matrix $G$ ) in the complex plane:

- systems with negative eigen spectrum of the state matrix totally situated in the left semi-plane of the complex plane;

- systems with one positive eigenvalue in the spectrum;

- systems with more than one positive eigenvalues in the spectrum;

- systems with complex conjugate eigenvalues.

Within the traditional concept, the first type represents a stable system; however it is considered to be unstablein economics. Negative real parts of eigenvalues demonstrate the imminent fall in all economic activities to zero, which is illustrated in figure 2. It shows the data on the output in the corresponding economic activities in Russian economy and results of approximation when applying the first-type

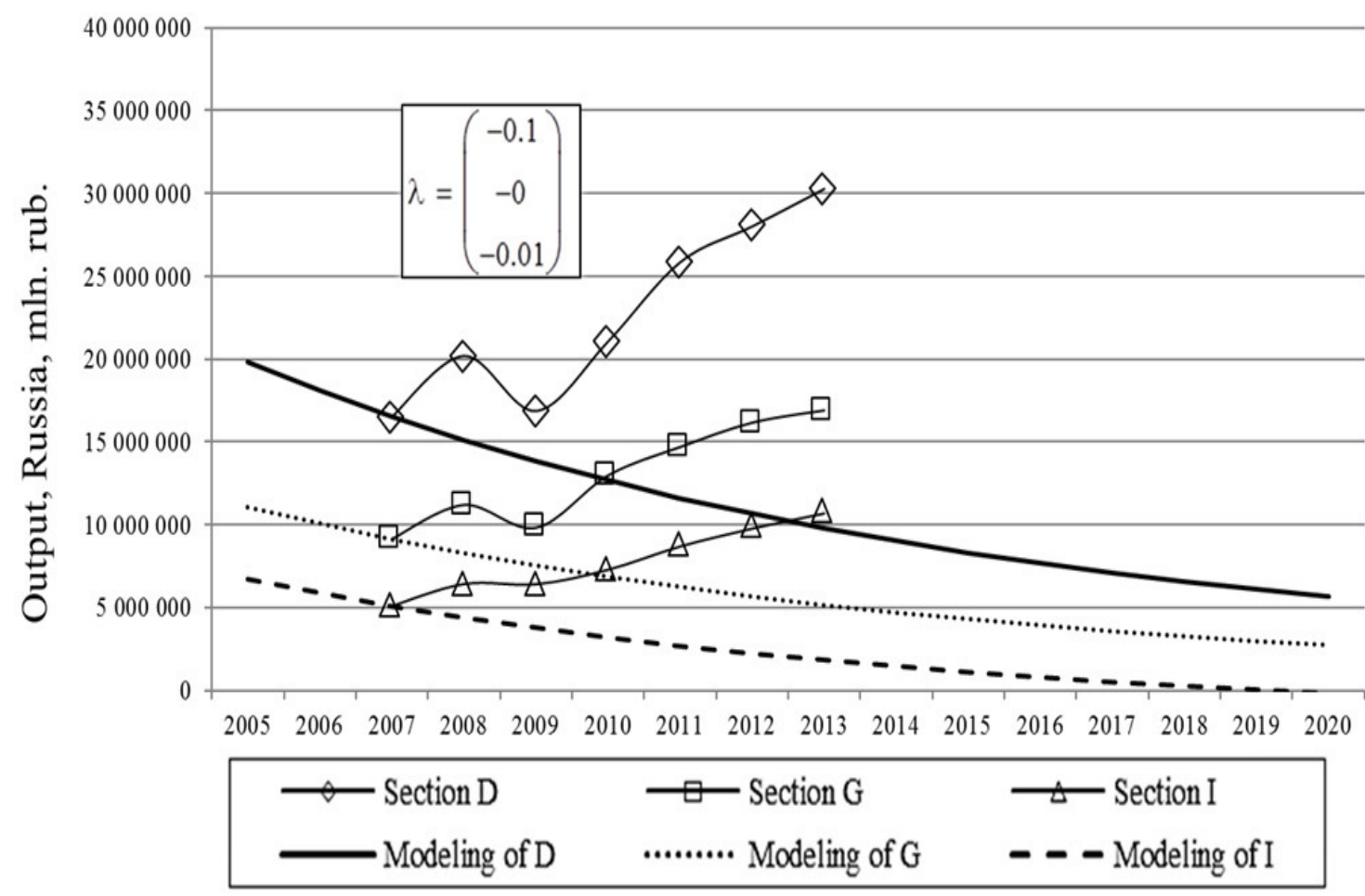

Figure 2. Eigenvalue spectrum and modeling of the decrease in gross output 
model. The crisis of 2009 can be seen in the data on both national and regional output. The trends in gross output components show only negative eigenvalues in the period of crisis, which resulted in the decreased gross output.

If in the matrix spectrum of a close-ended system one eigenvalue is positive and the others are negative, such system becomes capable of self-reproducing growth in gross output which will be balanced due to the trend components defined by negative eigenvalues will decay and the growth will be subject to one trend component with positive eigenvalue. This balanced growth, which can be considered as the main line, is shown in figure 3.

A quite complicated figure of the output variation in time can be seen if matrix $G$ spectrum includes more than one positive eigenvalue. It should be mentioned that this fact does not mean the presence of the economic growth.

The transient process in such system includes the growth in output of some economic activities and the fall in the output of others, as shown in figure 4. This economic trend indicates the mistake in limited resources allocation when some economic activities are considered dominant in the region and are allocated excessive amounts of resources, which leads to the underfunding of others. The territory (the region, the economic area, the country) which suffers from such mistake will be forced to import the deficient goods including those which could have been produced efficiently on site.

If matrix $\mathrm{G}$ spectrum includes complexconjugate pairs of eigenvalues, business cycles can be seen in the system, which is shown in figure 5. It is evident that it is advisable to choose the second-type macromodels with one positive eigenvalue to provide balanced growth and continuous increase in gross output. This eigenvalue is called the rate of economic growth.

The algebraic explanation of this

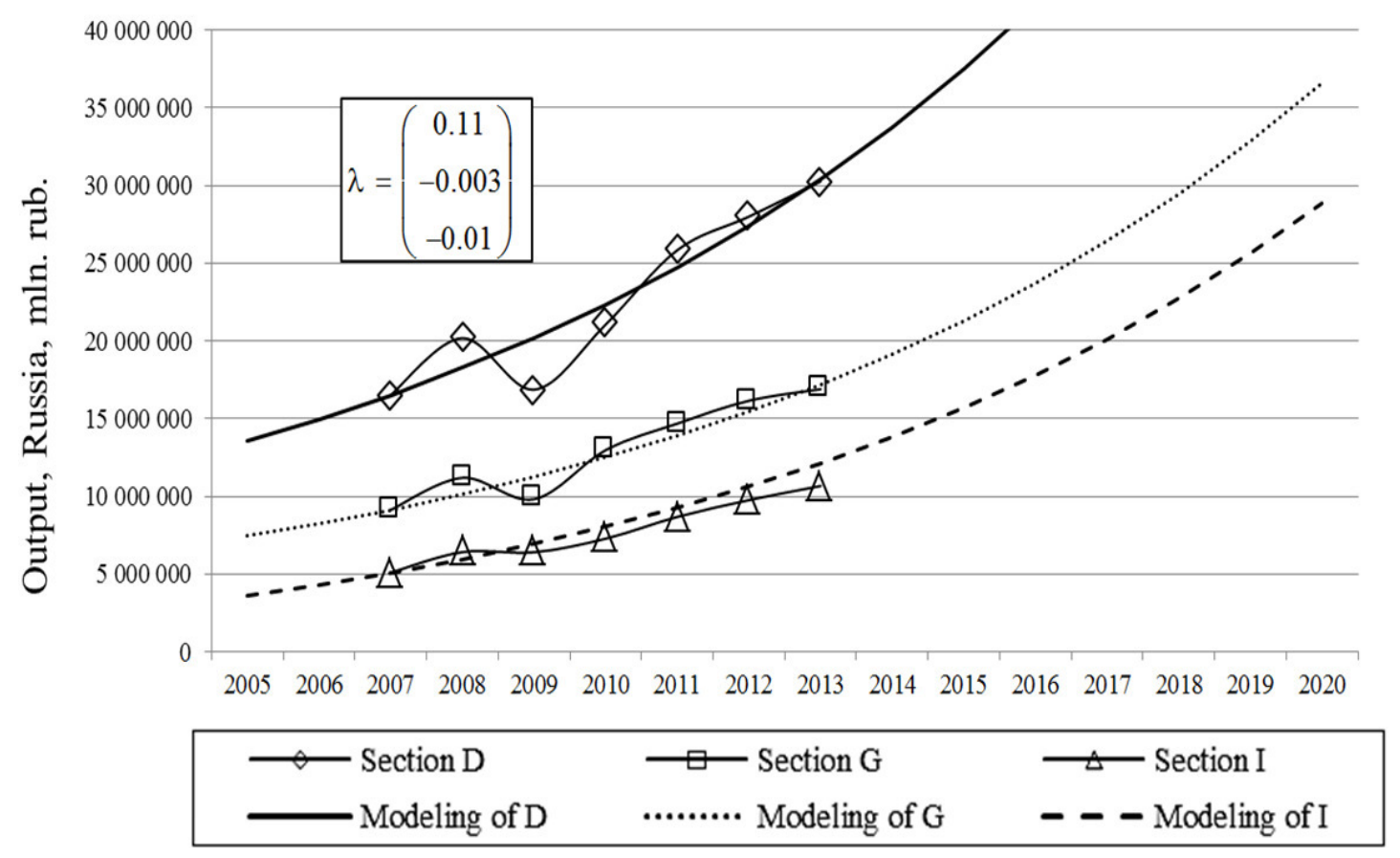

Figure 3. Output approximation by the second-type macro-model system 


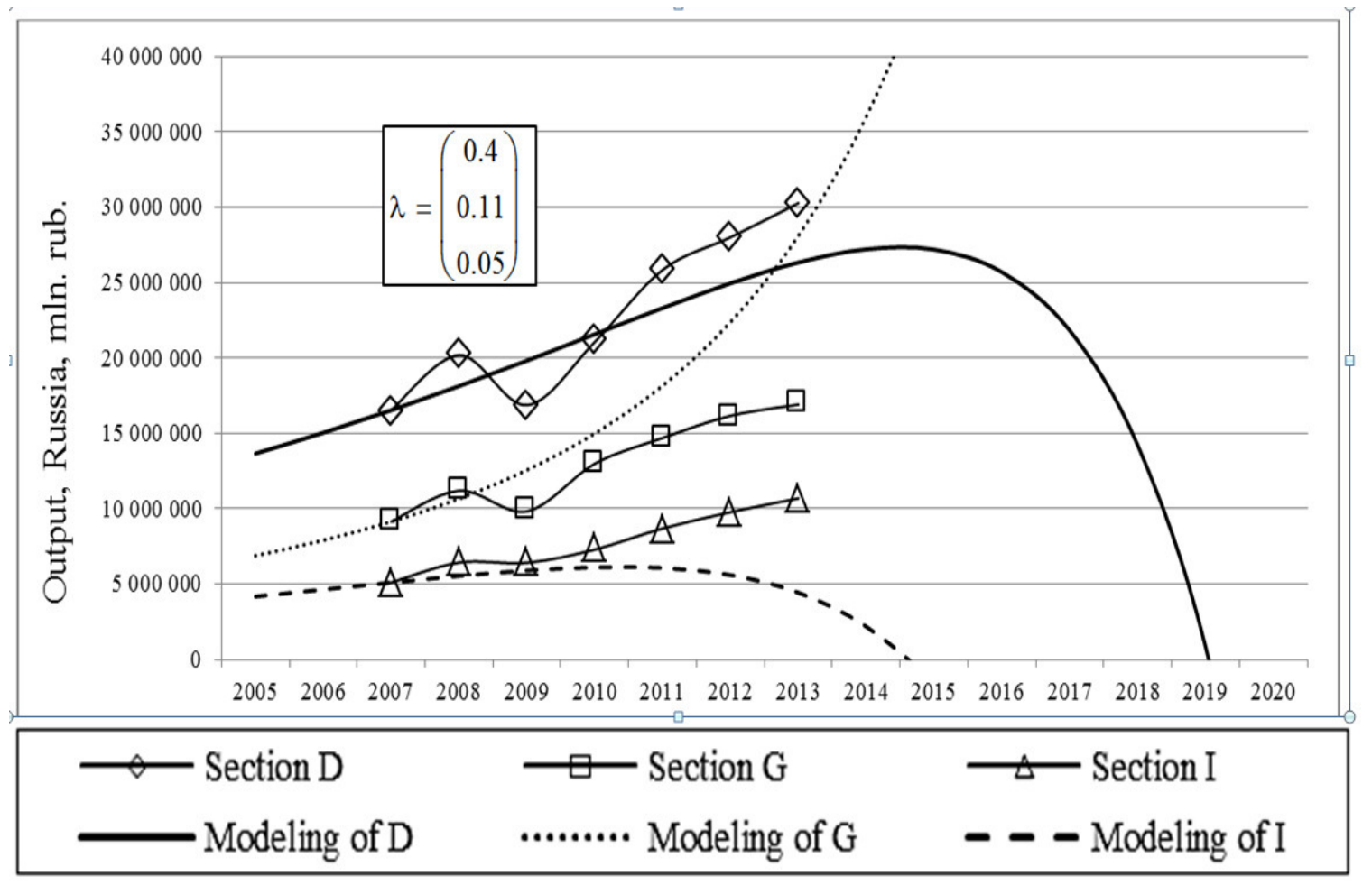

Figure 4. Competition effect on the third-type model system

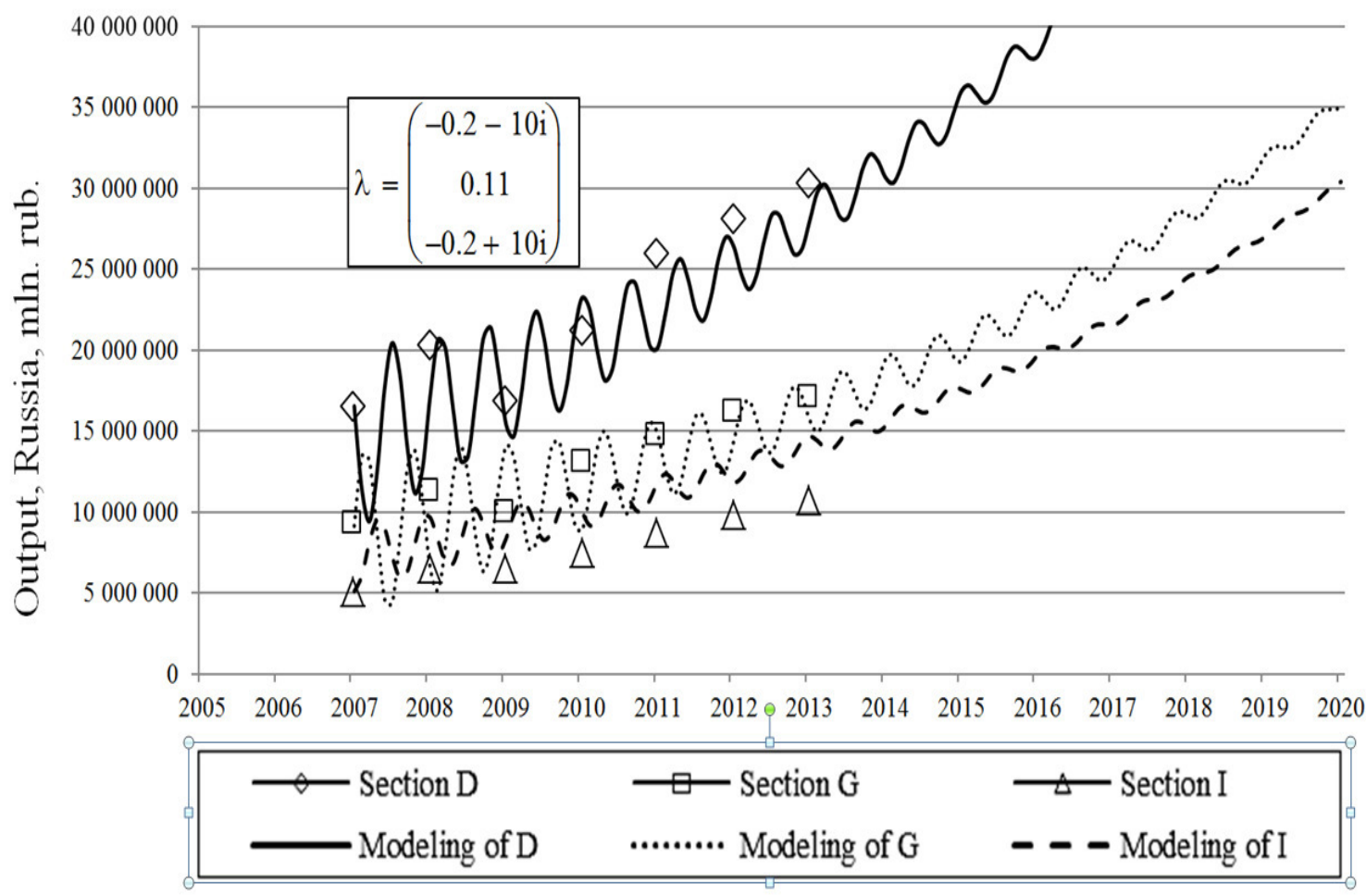

Figure 5.The model representation of fluctuations in the forth-type macro-system 
eigenvalue and the corresponding eigenvector is very often referred to PerronFrobeni us theorem, but it is not always correct as a close-ended matrix can include negative coefficients while the theorem can be applied to positive matrices only.

The inverse of matrix $\mathrm{G}$ must be positive, which is due to productivity of the inter industry balance model, i.e. $(E-A-Q)^{-1}>0$. Moreover, incremental capital coefficient of matrix B must be positive for the result of multiplication of two positive matrices to be a positive matrix as well. Leontyev eases fair requirement of positive inverse of matrix $G$ (Leontief, 1953), pointing out the possibility of negative coefficients in matrix $B$. The components of this matrix are calculated by the following formula:

$$
b_{i j}=\frac{S_{i j}}{\overline{X_{j}}}=\frac{\Delta I_{i j}}{\overline{X_{j}}\left(d_{i j}+R_{j}\right)}, \Delta I_{i j}=S_{i j} d_{i j}+S_{i j} R_{j}=S_{i j}\left(d_{i j}+R_{j}\right),
$$

where $S_{i j}$ is the cost of capital stock produced in external business activity $i$ and used in economic activities $j$ in current prices;

$\bar{X}_{J}$ is the production capacity of industry $\mathrm{j}$, defined as the cost of its products in current prices;

$d_{i j}$ is the annual depreciation rate of capital stock used in economic activities $i$ and produced in economic activities $\mathrm{j}$;

$R_{j}$ is the annual rate of change in the production capacity of industry $\mathrm{j}$;

$\Delta \mathrm{I}_{\mathrm{ij}}$ are investments (expenses) in economic activities $j$ to change the cost of their productive assets which are created in economic activities $i$.

Inparticular periods, indicator $\mathrm{R}_{j}$ can be negative and exceed negative value $d_{i j}$ of the corresponding incremental capital coefficient $b_{i j}$ in modulus.

If at the certain stage of the economic development matrix $G$ becomes general matrix with one eigenvalue and one eigenvector remaining positive, it indicates the inertial development of the economic system.

At $\mathrm{R}_{\mathrm{j}} \geq 0$, the presence of a positive eigenvector and the corresponding positive real eigenvector shows the possibility of balanced economic growth focused on the gradual achievement of structural and dynamic harmonization of the country's economic system. Among other factors, such modeled growth can be achieved with the solution of the optimization problem on shifting this value to the right semi-plane of the complex plane.

Thus, applying dynamic models after having solved the optimization problem of managing intrinsic dynamic properties of the subject, we can receive a long-term pattern of the balanced economic growth, as shown in figure 6.

Considering the economy of Stavropol region as the example of a regional economy, one can notice that the model allows taking the impact of 2009 crisis into account as well as creating and controlling the proportions of the development in all economic activities with the desired growth rate.

\section{CONCLUSIONS}

In conclusion, it should be mentioned that the approach to modeling the dynamic properties of complex economic systems, which include the national economic system in particular, suggested by the authors provides the opportunity to investigate the 


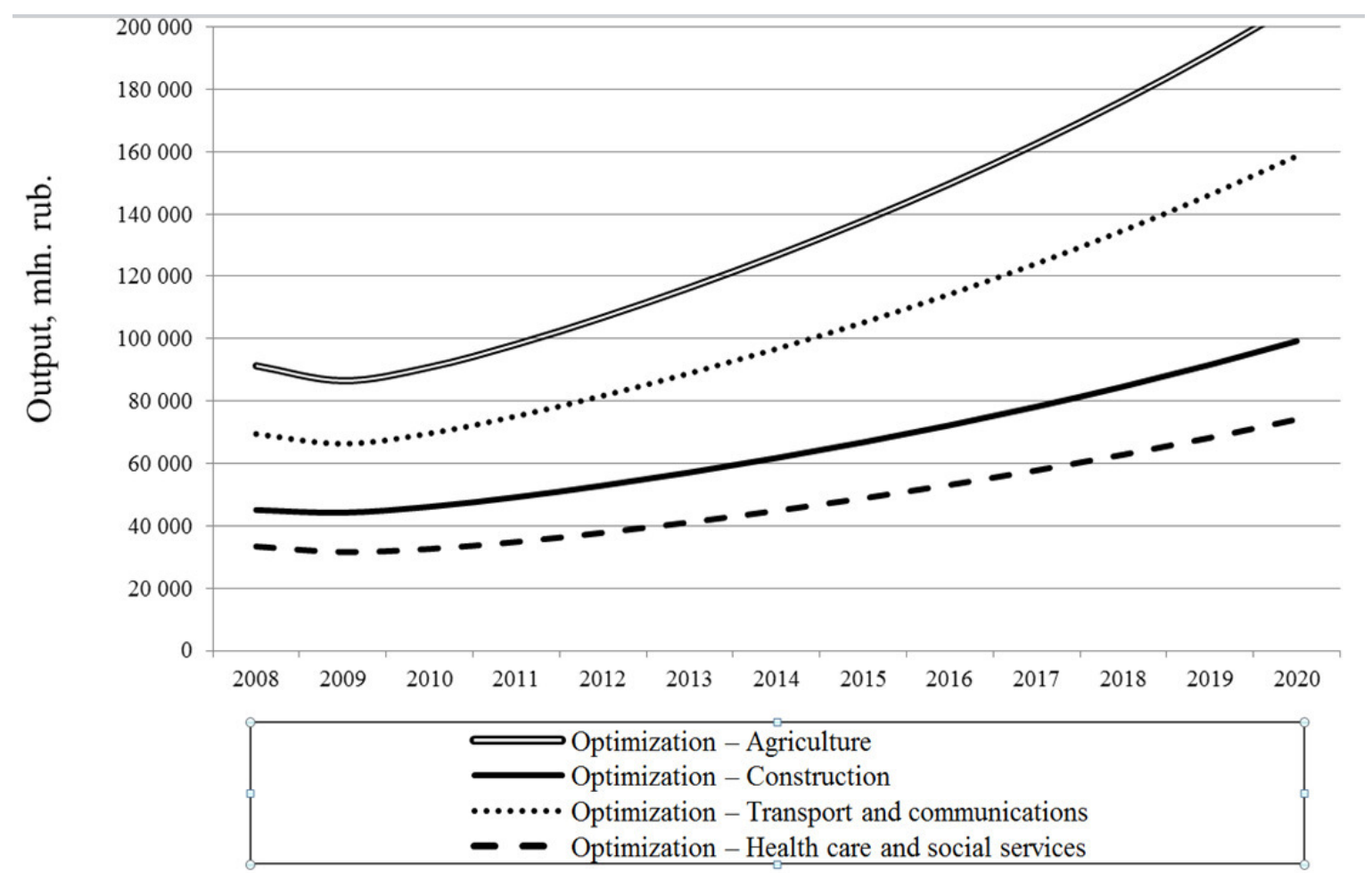

Figure 6. Stavropol region balance output growth path

dominant factors of its development and apply these results to managing structural shifts to reach the strategic goals and structural and dynamic harmonization of the country's economic growth. If the necessary economic and statistical support is available, the suggested models could be used to make high-quality forecasts, develop economic development strategies, make laws which will be genetically linked and related to similar laws on managing national and regional output.

As opposed to neoclassical models of economic dynamics that allow establishment of a cause and effect relationships of macroeconomic indicators on the theoretical and methodological level, but do not provide forecasting of management impacts on the economic growth, the model proposed in the article allows to solve these problems on the empirical level. In the development of dynamic input-output models of Leontiev, which have always been positioned as "purely theoretical", the model, proposed in this article, allows to examine and manage such economic indicators of economic dynamics as the frequency and decay of the individual components of the economic system motions, to assess their excitability, observability and controllability, and to identify and manage limiting factors of economic development in the strategic aspect using the methods of the classical theory of systems and system analysis.

The novelty of the conducted research is that the authors propose a fundamentally new approach to the analysis of own (internal) dynamic properties of complex economic systems in a linearized formulation, alternatives to which do not exist in the modern theory and practice of strategic management of socio-economic 
МОДЕЛОВАЊЕ ДИНАМИЧКИХ ОСОБИНА НАЦИОНАЛНИХ ЕКОНОМСКИХ СИСТЕМА

\author{
Vitaliy A. Korolev, Yevgeniy L. Toroptsev, G. Lyudmila Matveeva, Olga A. Chernova
}

\title{
Извод
}

Циљ овог чланка је описати моделовање динамичких особина националних економских система на различитим хијерархијским нивоима из универзалне статистичке и математичке перспективе теорије моделовања динамичког економског система. Узимајући у обзир предложени модел, у чланку су проучени главни фактори економског развоја садашње Русије. Методологија социо-економске анализе примењена је на процену утицаја идентификованих фактора на квантитативне и квалитативне показатеље развоја руске економије. Чланак описује улогу анализе динамичких карактеристика националне економије у повећању ефикасности управљања стратегијама развоја националне економије како би се постигла структурна и динамичка хармонизација иновативних процеса и економског раста.

Кључне речи: економски раст, национална економија, национална политика, динамичка својства система, моделирање економског система, управљање циљевима

systems neither in economic theory ,nor in management theory. Thus, our work showed an example of self-organization of science, when the results of one of its branch, transferred to another one, are able to give fruitful and unattainable by other methods results.

The universality of the presented modeling tools must be noted as it makes it possible to use them in the investment design of development of various countries and particular regions, as well as in the development of evidence-based strategies for socio-economic development of territories.

\section{Acknowledgment:}

The article was prepared with the financial support of the Russian Foundation for Basic Research. Grant No. 18-01000193A "Expansion of Information and Analytical Capabilities of CGE-Models Based on Dynamic Input-Output Balance".

\section{References}

Clark, J. B. (2000). The Distribution of wealth. Moscow, RUS: Gelios ARV.

Hansen, E. (2006). Monetary theory and fiscal policy. Moscow, RUS: Delo.

Harrod, R. (2008). Theory of economic dynamics. Moscow, RUS: CEMI Russian Academy of Sciences.

Jevons, W. S. (1905). Political economy. Saint Petersburg, RUS: National benefit. (In Russian)

Keller, A.V. \& Shishkina, T. A. (2013). Methodology for constructing dynamic and static balance models at the level of the enterprise. Bulletin of South Ural state University. Series: Economics and management, 7(3), 6-11. (In Russian)

Keynes, John. M. (2011). The General theory of employment, interest and money. Moscow, RUS: Helios ARV.

Kleiner, G. B. (1986). The Production function: theory, methods, application. Moscow, RUS: Finance and statistics. 
Leontief, W. (1953). Studies in the Structure of the American Economy. NewYork, USA: Oxford University Press.

Leontief, W. (1997). Interbranch economy. Moscow, RUS: Economics.

Marshall, A. (2007). Foundations of economic science. Moscow, RUS: Eksmo.

(In Russian)

Matveeva, L. G., Mikhalkina, E. V., Chernova, O. A., \& Nikitaeva, A. Yu. (2015). The strategic context of interaction between financial and real sectors of the Russian economy. Journal of Applied Economic Sciences, 7 (37), 1085-1092.

Salin, V. N., Medvedev, V. G., Medvedev ,A.V. (2012). Methodology and design of tables "expenses-release" in the format of economic activities. Moscow, RUS: Financial University.

Say, J. B. (1833). Catechism of political economy, or a Brief teaching on the preparation, distribution and consumption of wealth in society. Saint Petersburg, RUS: Type.

Solow, R. M. (2010). Stories about economics and technology. European Journal of the History of Economic Thought, 17 (5), 1113-1126.

Svetunkov, S. G., \& Abdullaev, I. S. (2009). Economic Dynamics and Production Functions. Bulletin of the Orenburg State University, 5, 110-114.

Tinbergen, Jan. (1980). The revision of the international order. Moscow, RUS: Progress.

Walras, L. (2000). Elements of pure political economy or the Theory of private wealth. Moscow, RUS: Economy. 